\title{
POLITIK LEGISLASI HUKUM TIDAK TERTULIS \\ DALAM PEMBANGUNAN HUKUM NASIONAL
}

(The Politics of Unwritten Law Legislation in the Development of the National System of Law)

\author{
Erlina Maria Christin Sinaga \\ Pusat Penelitian dan Pengkajian Perkara, dan Pengelolaan Perpustakaan \\ Mahkamah Konstitusi Republik Indonesia \\ Jalan Medan Merdeka Barat Nomor 6, Jakarta Pusat \\ Email: erlina.maria@mkri.id \\ Sharfina Sabila \\ Pusat Penelitian dan Pengkajian Perkara, dan Pengelolaan Perpustakaan \\ Mahkamah Konstitusi Republik Indonesia \\ Jalan Medan Merdeka Barat Nomor 6, Jakarta Pusat \\ Email: office@mkri.id
}

Naskah diterima: 7 Februari 2019; revisi: 28 Februari 2019; disetujui: 19 Maret 2019

\begin{abstract}
Abstrak
Hukum adat merupakan hukum yang berasal dari hukum tidak tertulis yang masih hidup dan berkembang dalam masyarakat. Penelitian ini bertujuan untuk mengetahui keberlakuan hukum adat dalam sistem penegakan hukum di Indonesia dan politik legislasi hukum adat dalam pembangunan hukum nasional. Penelitian ini merupakan penelitian yuridis normatif dengan meninjau keberlakuan hukum tidak tertulis di beberapa daerah dan menganalisis Putusan Mahkamah Konstitusi No. 35/PUU-X/2012. Pertama, setiap daerah di Indonesia memiliki adat istiadat yang berbeda antara satu daerah dengan daerah yang lainnya, khususnya dalam hal penegakan hukum yang ada. Kondisi ini harus diakomodir dalam sistem hukum nasional yang ada, meskipun tidak optimal dalam pengaturannya. Kedua, RUU Masyarakat Adat yang ada saat ini belum mampu mengakomodir kondisi masyarakat adat yang ada. Pemerintah perlu melakukan peninjauan ulang terkait hal tersebut, sehingga politik legislasi dalam RUU Masyarakat Adat mampu mencerminkan semangat kebhinekaan sebagaimana terdapat dalam UUD 1945.
\end{abstract}

Kata kunci : hukum tidak tertulis, masyarakat hukum adat, UUD NRI Tahun 1945

\begin{abstract}
Custom law comes from unwritten law that is still alive and growing in the society. This research aims to find out the existence of custom law in the law enforcement system in Indonesia and the politics legislation on custom law in the development of national law. This research is a normative juridical study, conducted by reviewing the existence of unwritten law in several regions and analyzing the decision of the Constitutional Court No. 35 / PUU-X / 2012. First, every region in Indonesia has different, especially in law enforcement. This condition must be accommodated in the current national law system, although it is not optimal in its regulation. Secondly, the current Indigenous People Bill has not been able to accommodate the existing conditions of indigenous people. The government needs to conduct a review regarding this matter, so that the political legislation in the Indigenous People Bill can reflect the spirit of diversity as contained in the 1945 Constitution.
\end{abstract}

Keywords: unwritten law, indigenous people, 1945 Constitution 


\section{A. Pendahuluan}

Kehidupan bermasyarakat tidak hanya diatur oleh hukum akan tetapi harus berpedoman juga kepada agama, moral, kesopanan dan kaidah sosial lainnya. Hukum erat hubungannya dengan kaidah sosial. Hukum sebagai kaidah sosial tidak lepas dari nilai yang berlaku dalam suatu masyarakat. Hukum sebagai cermin dari nilai-nilai yang hidup dalam masyarakat. Hukum disebut baik apabila sesuai dengan hukum yang hidup (the living law) dalam masyarakat. ${ }^{1}$

Indonesia disebut sebagai Negara Hukum berdasarkan Pasal 1 ayat 3 Undang-Undang Dasar 1945. Hukum bersumber dari nilai - nilai yang hidup di masyarakat baik yang sifatnya tertulis maupun tidak tertulis, di mana sumber hukum yang tidak tertulis ini banyak sekali ditemui di Indonesia. Wujud dari hukum tidak tertulis ini dapat berupa hukum adat maupun kearifan lokal (local wisdom) yang eksistensinya tetap diakui sebagai sebuah norma dan mempunyai daya ikat dan sanksi.

Pada pasal 18 ayat 2 Undang-Undang Dasar 1945 menyebutkan bahwa "Indonesia mengakui eksistensi hukum adat dan hak - hak tradisionalnya". ${ }^{2}$ Hakim dan hakim konstitusi wajib menggali, mengikuti, dan memahami nilai-nilai hukum dan rasa keadilan yang hidup dalam masyarakat. ${ }^{3}$ Selain itu, putusan pengadilan di samping harus memuat alasan dan dasar putusan, juga memuat pasal tertentu dari peraturan perundang-undangan yang bersangkutan atau sumber hukum tak tertulis yang dijadikan dasar untuk mengadili ${ }^{4}$.
Kemudian pada Pasal 8 ayat 4 UndangUndang Nomor 16 Tahun 2004 disebutkan bahwa jaksa senantiasa bertindak berdasarkan hukum dengan mengindahkan norma-norma keagamaan, kesopanan, kesusilaan serta wajib menggali dan menjunjung tinggi nilai-nilai kemanusiaan yang hidup dalam masyarakat. ${ }^{5}$

Gustav Radburch berpendapat bahwa pada dasarnya, hukum itu bertujuan untuk mewujudkan kepastian hukum, keadilan dan kemanfaatan. ${ }^{6}$ Ketika semua tujuan tersebut berbenturan maka yang dikedepankan adalah kemanfaatan. Tujuan yang ingin dicapai dalam hukum pidana tidak hanya semata kepastian hukum akan tetapi keadilan terlebih kemanfaatan. Namun kadang kala, putusan pengadilan pada praktiknya dapat melukai rasa keadilan karena ketidakseimbangan hukuman yang diterima. Hal ini dikarenakan para penegak hukum selalu mengartikan penegakan hukum secara tertulis. Aparat penegak hukum tidak menggali hukum yang hidup dalam masyarakat.

Namun, sesungguhnya penegakan hukum berbeda dengan penegakan undangundang. Menegakkan undang-undang selalu berdasarkan kepada aturan tertulis, sedangkan menegakkan hukum berdasarkan kepada hukum tidak tertulis. Oleh sebab itu dalam menegakkan hukum memang seharusnya diartikan menegakkan hukum yang hidup dalam masyarakat yang meliputi kearifan lokal (local wisdom).

Penegakan hukum yang dilakukan seharusnya dilakukan dengan menggunakan

\footnotetext{
Mochtar Kusumaatmaatmadja, Konsep-konsep hukum dalam Pembangunan (Pusat Studi Wawasan Nusantara: Alumni Bandung, 2002) hlm. 13-14.

Pasal 18 ayat 2 Undang-Undang Dasar 1945.

Pasal 5 Undang-Undang Nomor 48 Tahun 2009 tentang Kekuasaan Kehakiman.

Pasal 50 Undang-Undang Nomor 48 Tahun 2009 tentang Kekuasaan Kehakiman.

Pasal 8 ayat 4 Undang-Undang Nomor 16 Tahun 2004 tentang Kejaksaan Republik Indonesia.

6 Faisal, Menerobos Positivisme Hukum (Yogyakarta:Rangkang Education, 2010), hlm. 84.
} 
pendekatan kearifan lokal (local wisdom) demi mendapat keadilan yang substansi. Dalam arti bahwa penegakan hukum tidak hanya melihat pada aspek formal suatu perbuatan saja tetapi juga harus melihat bagaimana hukum yang hidup di lingkungan masyarakat sekitar. Apabila suatu perbuatan hanya melihat pada masalah hitam putih pasal saja di mana tersangka dapat diproses secara hukum karena perbuatan yang dilakukan melanggar undang-undang tertulis secara formal saja, maka keadilan yang kemudian didapat adalah keadilan yang formal prosedural. $^{7}$

Keadilan yang substansial dapat diperoleh jika aparat penegak hukum mampu dan mau melakukan reparadigma dan reinterpretasi terhadap arti dan makna dari penegakan hukum serta mencari keadilan yang betulbetul tidak melukai rasa keadilan, misalnya dengan melakukan perdamaian jika kerugian yang ditimbulkan tidaklah begitu besar jika dibandingkan dengan vonis yang akan dijatuhkan, mediasi di tingkat penyidikan, permaafan, mengingat bangsa kita adalah bangsa yang mengedepankan musyawarah.

Masyarakat yang masih berpegang pada hukum tidak tertulis seperti halnya pada aturanaturan adat, penyelesaian permasalahan dengan hukum adat akan dirasakan lebih memberikan manfaat keadilan dibandingkan dengan hukum nasional yang kadang kala penegakannya tajam ke bawah tumpul ke atas. Hukum yang berlaku dalam masyarakat terkesan berbeda berdasarkan strata sosialnya. Masyarakat yang memiliki kedudukan atau jabatan tinggi cenderung diperlakukan istimewa, sedangkan masyarakat biasa cenderung diperlakukan tidak adil. Fenomena ketidakadilan penegakan hukum yang demikian hampir terjadi di setiap penjuru tanah air Indonesia. ${ }^{8}$ Selain itu, harapan masyarakat adat untuk meminta pengakuan dan perlindungan hak sebagai masyarakat hukum adat sampai saat ini belum ada. Hal ini dikarenakan Rancangan Undang-Undang Masyarakat Adat masih dalam program legislasi nasional.

Presiden Joko Widodo telah berkomitmen untuk menghadirkan Komisi Nasional Masyarakat Adat dalam fungsi pendataan, pengkajian, pendidikan, maupun penyelesaian konflik dalam masyarakat adat sebagai manifestasi Nawa Cita. Namun belum ada realisasi sampai sekarang, oleh sebab itu perlu ditindaklanjuti sebagai bukti keseriusan pemerintah dalam menghormati keberadaan Masyarakat Adat. ${ }^{9}$

Rancangan Undang-Undang MasyarakatAdat sangatlah penting karena mengingat ketiadaan hukum tentu akan menimbulkan masalah bagi pemerintah dan rakyat. Harapannya UndangUndang Masyarakat Adat dapat menjadi dasar ketika menyelesaikan setiap konflik yang terjadi dalam masyarakat.

Berdasarkan uraian tersebut, keberadaan hukum tidak tertulis sebagai hukum yang hidup dalam masyarakat masih terus dipertahankan

Chandra Lumban Toruan dalam artikel Kearifan Lokal Sebagai Asas Penegakan Hukum Untuk Keadilan Yang Substansi http://www.academia.edu /23515607/KEARIFAN_LOKAL_SEBAGAI_ASPEK PENEGAKAN_HUKUM_ UNTUK_KEADILAN_YANG_SUBSTANSI (diakses pada 22 Januari 2019)

8 Alfan Biroli dalam artikel Problematika Penegakan Hukum Di Indonesia (Kajian Dengan Perspektif Sosiologi Hukum ), Universitas Trunojoyo Madura.

9 https://news.detik.com/kolom/3975715/penantian-panjang-ruu-masyarakat-adat (diakses pada 27 Januari 2019). 
dalam menegakkan hukum dan keadilan. Oleh sebab itu penulis ingin mengkaji mengenai bagaimana keberlakuan hukum tidak tertulis dalam penegakan hukum saat ini dan bagaimana politik legislasi hukum tidak tertulis dalam pembangunan hukum nasional.

\section{B. Metode Penelitian}

Penelitian ini merupakan jenis penelitian hukum normatif dengan fokus kajian terhadap keberlakuan hukum tidak tertulis dalam penegakan hukum dan politik legislasi hukum tidak tertulis dalam sistem hukum nasional. Normatif dalam hal ini mengenai asas-asas, norma, kaidah dari peraturan perundangan, perjanjian serta doktrin (ajaran). ${ }^{10}$ Dalam hal ini yang diteliti hanya bahan pustaka atau data sekunder yang mencakup bahan hukum primer, bahan hukum sekunder, dan bahan hukum tersier. Bahan hukum primer yakni bahan hukum yang mengikat yang terdiri dari norma dan peraturan perundang-undangan. Kemudian bahan hukum sekunder, bahan yang dapat membantu menganalisis bahan hukum primer seperti hasil karya ilmiah para ahli/ sarjana, jurnal maupun putusan pengadilan. Selanjutnya, bahan hukum tersier yaitu bahan hukum yang memberikan penjelasan terhadap bahan hukum primer dan sekunder seperti bahan- bahan internet.

Pendekatan yang dilakukan dalam penelitian ini adalah pendekatan historis (historical approach) dengan cara meneliti keberlakuan hukum adat di beberapa daerah hukum adat di
Indonesia. Selain itu juga dilakukan pengkajian terhadap putusan Mahkamah Konstitusi Nomor 35/PUU-X/2012 mengenai hutan adat. Penelitian hukum ini dilakukan untuk memecahkan isu hukum yang diajukan. Hasil yang hendak dicapai adalah deskripsi mengenai apa yang seyogianya. ${ }^{11}$

\section{Pembahasan}

\section{Keberlakuan Hukum Tidak Tertulis dalam Penegakan Hukum Saat Ini}

Hukum adat diartikan sebagai hukum Indonesia asli yang tidak tertulis dalam bentuk perundang-undangan Republik Indonesia yang mengandung unsur agama. ${ }^{12}$ Jauh sebelum Indonesia merdeka bahkan sebelum kedatangan bangsa Eropa ke bumi nusantara, masyarakat hukum adat sudah mempunyai sistem hukum sendiri yang dijadikan pedoman dalam pergaulan hidup masyarakat. Wujud hukum adat berupa hukum yang tidak tertulis, hukum yang tertulis (bagian terkecil ditemui dalam lingkungan masyarakat adat seperti peraturan perundang-undangan yang dikeluarkan oleh raja-raja atau sultan-sultan dahulu), dan uraianuraian hukum secara tertulis. ${ }^{13}$

Von Savigny mengemukakan, hukum mengikuti Volkgeist masyarakat berdasarkan tempat berlakunya hukum karena masingmasing Volkgeist masyarakat berbeda-beda. Demikian juga dengan hukum adat Indonesia, tumbuh dan dipertahankan oleh masyarakat adat sebagai sumber kebudayaan masyarakat hukum adat masing-masing itu berasal. Oleh

10 Mukti Fajar dan Yulianto Achmad, Dualisme Penelitian Hukum Normatif dan Empiris $\quad$ (Yogyakarta: Pustaka Pelajar, 2010), hlm. 34.

11 Peter Mahmud Marzuki, Penelitian Hukum (Jakarta: Kencana, 2011), hlm. 89.

12 Menurut Kesimpulan Hasil Seminar Hukum Adat dan Pembangunan Hukum Nasional, dalam buku Rosdalina, Hukum Adat (Yogyakarta: Penerbit Deepublish, 2017), hlm 39.

13 Rosdalina, Ibid, hlm. 45. 
sebab itu keberlakuan hukum adat tergantung kepada masing-masing wilayah. Ada 2 hal yang menjadi batasan wilayah berlakunya hukum adat, antara lain: ${ }^{14}$

a. Kebudayaan dalam masyarakat, karena pada dasarnya pelanggaran adat adalah aspek dari kebudayaan;

b. Masyarakat, tempat lahir, tumbuh, berkembang, dan lenyapnya pelanggaran adat. Hubungannya bahwa pelanggaran adat dipandang sebagai pelanggaran dinilai berdasarkan struktur masyarakatnya.

Dalam sistem hukum Indonesia, hukum adat sebagai hukum tidak tertulis (unstatuta law) berbeda dengan hukum continental sebagai hukum tertulis (statute law). Koesno berpandangan bahwa nilai-nilai yang menjadi dasar hukum adat antara lain: ${ }^{15}$

a. Individu adalah bagian dari masyarakat yang mempunyai fungsi masing-masing demi untuk melangsungkan dan kelangsungan masyarakat (sebagai lingkungan kesatuan);

b. Setiap individu dalam lingkungan kesatuan itu bergerak berusaha sebagai pengabdian kepada keseluruhan kesatuan;

c. Dalam pandangan adat yang demikian mengenai kepentingan individu, maka sulit untuk mengemukakan setiap kepentingan para individu. Dalam adat, ketertiban ada dalam alam semesta.

d. Dalam pandangan adat, ketentuan adat tidak harus disertai dengan syarat menjamin berlakunya dengan jalan mempergunakan paksaan.
Sebagai hukumyang tidaktertulis dan berlaku pada semua bidang kehidupan masyarakat. Dalam penegakan hukum seyogianya memang harus memperhatikan suatu sistem hukum yang tidak mengacu pada peraturan tertulis dalam undang-undang. Undang-undang yang berlaku digali dari nilai-nilai yang hidup dalam masyarakat sebagai hukum tidak tertulis yang meliputi kebiasaan, hukum adat dan kearifan lokal. Hukum tidak tertulis diakui keberlakuannya sebagai hukum yang hidup dan memiliki daya ikat beserta sanksi.

Sebagai negara hukum, Indonesia menghormati kesatuan masyarakat hukum adat beserta hak-hak tradisional. ${ }^{16}$ Pasal ini memberikan pengakuan dan penghormatan bagi kesatuan masyarakat hukum adat beserta hak tradisionalnya harus memenuhi syarat sebagai berikut:

a. Sepanjang masih hidup;

b. Sesuai dengan perkembangan masyarakat;

c. Sesuai dengan prinsip Negara Kesatuan Republik Indonesia;

d. Diatur dalam Undang-Undang.

Hukum adat adalah aturan tidak tertulis yang hidup di dalam masyarakat adat suatu daerah dan akan tetap hidup selama masyarakatnya masih memenuhi hukum adat yang telah diwariskan kepada mereka dari para nenek moyang sebelum mereka. Oleh karena itu, keberadaan hukum adat dan kedudukannya dalam tata hukum nasional tidak dapat dipungkiri walaupun hukum adat tidak tertulis

14 Anto Soemaman, Hukum Adat Perspektif Sekarang dan Mendatang (Yogyakarta: Mitra Gama Widya, 2003), hlm 11.

15 Laurensius Arliman, Hukum dan Kesadaran Masyarakat (Yogyakarta: Penerbit Deepublish, 2015), hlm 66-67.

16 Pasal 18B ayat (2) Undang-Undang Dasar 1945, Negara mengakui dan menghormati kesatuan-kesatuan masyarakat hukum adat beserta hak-hak tradisionalnya sepanjang masih hidup dan sesuai dengan perkembangan masyarakat dan prinsip Negara Kesatuan Republik Indonesia, yang diatur dalam Undang-Undang. 
dan berdasarkan asas legalitas adalah hukum yang tidak sah. Hukum adat akan selalu ada dan hidup di dalam masyarakat. Hukum Adat adalah hukum yang benar-benar hidup dalam kesadaran hati nurani warga masyarakat yang tercermin dalam pola-pola tindakan mereka sesuai dengan adat-istiadatnya dan pola sosial budayanya yang tidak bertentangan dengan kepentingan nasional.

Untuk mengetahui kedudukan hukum adat bila dihubungkan dengan aliran Sociological Jurisprudence yang dikemukakan oleh Eugen Ehrlich tentang konsepsi pemikirannya dengan living law. Sebagai hukum positif yang efektif, maka penegakan hukumnya harus sesuai dengan living law dari masyarakat sekaligus mencerminkan nilai-nilai yang hidup di dalamnya. ${ }^{17}$

Masalah penegakan hukum sesungguhnya masalah yang dihadapi oleh setiap masyarakat yang karakteristiknya memberikan persoalan tersendiri dalam penegakan hukumnya. Tetapi setiap masyarakat pasti mempunyai tujuan yang sama supaya tercipta kedamaian dalam penegakan hukum tersebut.

Dalam penelitian ini, penulis mengkaji bagaimana dinamika dari keberlakuan hukum adat dalam penegakan hukum di Indonesia mengingat hukum adat tidak mengenal sistem pelanggaran hukum seperti halnya yang terdapat dalam Pasal 1 ayat 1 KUHP bahwa suatu perbuatan tidak dapat dipidana, kecuali berdasarkan kekuatan ketentuan perundangundangan yang telah ada. Namun dalam hukum adat dikenal dengan yang namanya sanksi adat. Sanksi adat adalah sebagai usaha dalam mengatasi setiap permasalahan yang terjadi karena pelanggaran adat. Sanksi adat bertindak dalam menyeimbangkan antara dunia lahir dan dunia gaib. Wujud sanksi adat berdasar pada nilai-nilai dan keadilan masyarakat yang bersangkutan.

Setiap masyarakat membutuhkan cara untuk menyelesaikan permasalahan ataupun sengketa dalam menegakkan aturan yang hidup dalam masyarakat. Ketika menerapkan aturan dalam situasi baru ataupun mengubah aturan, tentunya masyarakat membutuhkan proses dalam pelaksanaanya. Pada praktiknya, setiap masalah dapat diatasi sehingga tercipta masyarakat yang aman dan sejahtera. Untuk mencapai tujuan tersebut, maka dalam setiap konflik yang terjadi dalam masyarakat harus diselesaikan sampai tuntas sehingga tidak menimbulkan persoalan di kemudian hari. ${ }^{18}$

Dalam menyelesaikan setiap pelanggaran, keberadaan hukum adat sebagai hukum yang tumbuh dalam masyarakat tidak dapat dipisahkan dari masyarakat. ${ }^{19}$ Musyawarah dan kekeluargaan selalu ditempuh oleh masyarakat hukum adat ketika terjadi permasalahan. Biasanya masyarakat selalu menempuh jalan damai dengan kesepakatan yang menguntungkan kedua belah pihak. Pola ini diterapkan dalam sengketa perdata ataupun sengketa pidana. Pada praktik sosialnya, telah ada lembaga mediasi penal atau cara perdamaian

Mochtar Kusumaatmaatmadja, Konsep-konsep hukum dalam Pembangunan (Pusat studi Wawasan Nusantara: Alumni Bandung, 2002), hlm. 13.

18 Mohammad Koesno, Hukum Adat Sebagai Suatu Model Hukum, Bagian I (Historis) (Bandung: Mandar Maju, 1992), hlm 11.

19 Ali Abubakar, Urgensi Penyelesaian Kasus Pidana Dengan Hukum Adat, dalam jurnal online http://www.academia. edu/19807132/URGENSI_PENYELESAIAN_KASUS_PIDANA_DENGAN_HUKUM_ADAT (diakses pada 26 Januari 2019). 
dalam hukum adat yang telah menjadi tradisi, seperti halnya pada:

a. Masyarakat Aceh

Lembaga adat di Aceh sudah eksis sebelum masuk dalam wilayah kesatuan NKRI. Masyarakat Aceh memiliki lembaga adat yang berwenang membentuk sejenis peradilan di wilayahnya masing-masing. Jadi setiap konflik yang terjadi diselesaikan berdasarkan akar munculnya permasalahan tersebut. ${ }^{20}$ Ketika terjadi permasalahan seperti kejahatan, utang piutang di antara kelompok masyarakat selalu diselesaikan oleh keuchik dan teungku meunasah yang dibantu oleh tuha peut. Mereka bertindak layaknya hakim dalam memutuskan setiap para pihak yang bermasalah. ${ }^{21}$ Aturan hukum yang berlaku di lembaga pengadilan adat berdasarkan syariah Islam, adat Meukuta alam, Sarakata Sultan Syamsul Alam serta kebiasaan adat yang berlaku. Namun pada kenyataannya hukum yang berlaku lebih berpegangan kepada hukum adat ketimbang hukum syariah. ${ }^{22}$

b. Masyarakat Kepulauan Nias

Masyarakat Nias sangat menghormati hukum adat yang berlaku yang dikenal dengan Fondrako sebagai hukum dan tata cara adat. Oleh sebab itu, mereka sangat patuh terhadap sanksi hukum adat Nias yang tergolong berat. Fondrako menjadi hal yang ditakuti dan mengerikan bagi setiap orang yang tinggal di Pulau Nias karena setiap peraturan yang telah ditetapkan tidak boleh dilanggar karena akan mendapat kutukan Fondrako. Mekanisme penetapan Fondrako melibatkan binatang dan benda yang dijadikan siksaan atau kutuk bagi si pelanggar. Hal ini terkesan mistis, oleh sebab itu masyarakat Nias sangat berpedoman kepada hukum adat dalam setiap berperilaku. ${ }^{23}$

c. Masyarakat Minangkabau

Dalam penanganan tindak pidana yang terjadi di masyarakat Minangkabau dilaksanakan oleh Badan Peradilan Nagari yang dikenal dengan sebutan Kerapatan Adat Nagari terdiri dari niniak mamak. Ketika mengadili perkara harus berdasarkan undang nan duo puluah serta peraturan tiaptiap nagari di Minangkabau. Hukuman yang dijatuhkan seperti kerja sosial kepada nagari berjangka waktu, membayar berupa denda, atau memberikan hukuman yang memenuhi rasa keadilan masyarakat setempat yang sekaligus memberikan efek jera kepada pelaku kejahatan. ${ }^{24}$

d. Masyarakat Megow Pak Tulang Bawang Masyarakat ini memiliki nilai kearifan lokal dalam menyelesaikan masalah. Hingga saat ini mereka tetap patuh dan menjalankan adat istiadat yang berlaku. Setiap penyelesaian perkara tindak pidana selalu dengan mediasi yang mengacu kepada ketentuan

20 T. M. Djuned, "Adat dalam Perspektif Perdebatan dan Praktek Hukum" dalam Lukman Munir, (ed.), Bunga Rampai Menuju Revitalisasi Hukum dan Adat Aceh (Banda Aceh: Yayasan Rumpun Bambu dan CSSP Jakarta, 2003), hlm 36.

21 M. Isa Sulaiman dan H.T. Syamsuddin, (ed.), Pedoman Umum Adat Aceh: Peradilan dan Hukum Adat (Banda Aceh: MAA Provinsi NAD, 2007-2008), hlm 2.

22 M. Isa Sulaiman, Ibid, hlm 3.

23 Artikel dalam Jurnal Ilmiah Pendidikan, Humaniora, Sains, dan Pembelajarannya, Amstrong Harefa, Eksistensi "Fondrako" Dalam Hukum Adat Nias.

24 H. Suardi Mahyuddin, Hukum Adat Minangkabau dalam Sejarah Perkembangan Nagari Rao-Rao (Citatama Mandiri, 2002), hlm 27. 
hukum adat Lampung. Hukum Adat Megow Pak Tulang Bawang adalah aturan yang bertujuan mempertahankan ketertiban masyarakat yang dalam penyelesaiannya secara mediasi serta sanksi denda seperti yang diatur dalam Pasal 42 ayat (11) Kitab Pelatoeran Sepandjang Hadat Lampung. ${ }^{25}$

Hukum adat diakui juga keberadaannya berdasarkan Undang-Undang Dasar 1945 yang menyebutkan, Negara kesatuan masyarakat hukum adat beserta hak-hak tradisionalnya sepanjang masih hidup dan sesuai dengan perkembangan masyarakat dan prinsip negara Kesatuan Republik Indonesia, yang diatur dalam undang-undang. ${ }^{26}$ Dari ketentuan tersebut berarti konstitusi menjamin penghormatan kepada hukum adat dengan syarat:

a. Hukum adat masih hidup dan sesuai perkembangan masyarakat;

b. Sesuai dengan prinsip negara kesatuan Republik Indonesia, dan keberlakuan diatur dalam undang-undang.

Dalam penegakan hukum pidana, sistem hukum pidana adat telah pernah diberlakukan dan masih dipertahankan sampai sekarang. Sistem hukum pidana adat berdasarkan kepada hukum adat di masing-masing wilayah yang pengaturannya sesuai dengan kebiasaan atau adat setempat. Hukum pidana adat secara materil telah dituangkan secara tertulis dalam
Undang-Undang Darurat Nomor 1 Tahun 1951, yang menyebutkan bahwa hukum materil sipil dan hukum materil pidana sipil untuk sementara waktu berlaku sampai kini bagi kaula-kaula daerah swaparaja dan orang-orang yang dahulu diadili oleh Pengadilan Adat. ${ }^{27}$ Tetapi pidana adat belum diatur secara formil dalam peraturan hukum positif Indonesia dan Kitab Undang-Undang Hukum Acara Pidana. ${ }^{28}$

Hukum pidana adat, sebagai hukum yang hidup dan berlaku dalam masyarakat dirasakan sebagai hukum yang adil dalam menyeimbangkan apabila terjadi suatu pelanggaran ataupun kejahatan. Pelanggaran adat menurut Barend Ter Haar B.Zn berupa gangguan dari pihak tertentu terhadap keseimbangan dari sekelompok orang yang menimbulkan reaksi adat dan pemulihannya harus berupa uang atau barang. ${ }^{29}$

Hukum pidana adat memiliki 3 pengertian pokok yaitu: ${ }^{30}$

a. Seperangkat peraturan yang dibuat oleh masyarakat adat yang bersangkutan untuk ditaati;

b. Perbuatan melanggar aturan dikenal dengan delik adat yang dapat menimbulan ketidakseimbangan karena adanya pelangggaran adat;

c. Pelaku yang melakukan pelanggaran akan dikenakan sanksi oleh masyarakat yang bersangkutan.

25 Artikel dalam Jurnal, Hendri Pratama, Penyelesaian Perkara Pidana Anak Secara Adat Lampung Megow Pak Tulang Bawang Dalam Rangka Restorative Justice, Fiat Justisia Journal of Law, Volume 10 Issue,1, January-March 2016.

26 Pasal 18D ayat 2 Undang-Undang Dasar 1945.

27 Dalam ketentuan Pasal 5 ayat (3) sub b Undang-Undang Darurat Nomor 1 Tahun 1951 tentang TindakanTindakan Sementara Untuk Menyelenggarakan Kesatuan Susunan Kekuasaan dan Acara Pengadilan-Pengadilan Sipil (LN 1951 Nomor 9).

28 Artikel dalam Jurnal: Stevania Bella Kalengkongan, Kajian Hukum Pidana Adat Dalam Sistem Hukum Pidana Indonesia, Jurnal Lex Crimen Vol. VI/No.2/Mar-Apr/2017.

29 Tolib Setiadi, Intisari Hukum Adat Indonesia dalam Kajian Kepustakaan (Bandung: Alfabeta, 2008), hlm 345.

$30 \quad$ I Made Widnyana, Kapita Selekta Hukum Pidana Adat (Bandung: Eresco, 1993), hlm 3. 
Dalam menegakkan hukum, selalu erat kaitannya dengan sistem peradilan pidana. Oleh sebab itu, kepolisian sebagai unsur yang utama dalam sistem peradilan pidana tentunya harus dapat efektif dalam menyelesaikan konflik di luar peradilan dengan mengikutsertakan korban, pelaku, masyarakat dan lembaga adat. Dengan demikian, cara seperti ini memberikan perlindungan kepada masyarakat. ${ }^{31}$ Dengan demikian, sebagai upaya untuk menurunkan tingkat kejahatan, sistem peradilan pidana tentunya tidak cukup untuk mengakomodir. Perlu adanya dukungan dari hukum adat dengan cara-cara yang tradisional. Masyarakat hukum adat di samping menggunakan penyelesaian setiap konflik secara kekeluargaan juga dapat menggunakan jalan mediasi di luar pengadilan sebagai proses untuk menyelesaikan konflik secara damai. Setiap konsensus atau mufakat dalam proses mediasi yang dihasilkan harus sesuai dengan kesepakatan para pihak dan saling menerima setiap persetujuan yang dihasilkan. ${ }^{32}$

Dari beberapa daerah yang coba penulis uraikan mengenai keberlakuan hukum tidak tertulis di masing-masing daerah, terdapat perbedaan antar daerah yang satu dengan daerah yang lainnya. Hal ini dikarenakan hukum yang hidup dalam masyarakat di suatu daerah berbeda, namun tujuan yang ingin dicapai sama, yaitu terciptanya kedamaian dan keteraturan hidup dalam bermasyarakat. Hal ini juga otomatis akan mendorong keteraturan dan ketertiban dalam skala nasional.

Namun, pada kenyataannya untuk mewujudkan sistem hukum nasional masih dihambat oleh banyaknya peraturan perundang-undangan yang sudah tidak sesuai dan tidak mampu menampung dinamika perubahan dalam masyarakat yang semakin kompleks. Upaya untuk mengisi kekosongan peraturan perundang-undangan telah dilakukan melalui optimalisasi fungsi dan peran dari yurisprudensi, pelaksanaannya belum optimal. Pada masa sekarang ini memang diperlukan pembangunan sistem hukum nasional untuk menjamin tegaknya supremasi hukum dan hak asasi manusia, mendukung proses tercapainya penegakan hukum, serta mendukung proses peningkatan nilai-nilai budaya hukum.

Hukum tidak tertulis sudah seharusnya diwujudkan ke dalam hukum positif yang walaupun tidak dapat merangkum semua hukum tidak tertulis antar daerah setidaknya dapat menjadi alat untuk mengakomodir sistem hukum tidak tertulis dalam hukum nasional. Sehingga nantinya hukum positif ini dapat disebutkan akan efektif apabila sesuai dengan hukum yang hidup dalam masyarakat.

\section{Politik Legislasi Hukum Tidak Tertulis dalam Pembangunan Hukum Nasional}

Salah satu Nawa Cita 9 (sembilan) Agenda Prioritas Jokowi-JK pada tahun 2014 lalu, adalah Memperteguh kebhinekaan dan memperkuat restorasi sosial Indonesia melalui kebijakan memperkuat pendidikan kebhinekaan dan menciptakan ruang-ruang dialog antar warga. Nawa cita tersebut merupakan prioritas kerja yang telah dilakukan oleh Jokowi-JK sejak terpilih di Pemilihan Presiden yang lalu demi berjalannya pembangunan hukum nasional di Indonesia. Bentuk konkret dari hal tersebut

\footnotetext{
31 Artikel dalam Jurnal: Pendekatan Hukum Adat Dalam Menyelesaikan Konflik Masyarakat Pada Daerah Otonom, Jurnal Kriminologi Indonesia Vol. 2 Nomor I Januari 2002.

32 Syukur Fatahillah, Mediasi Yudisial di Indonesia (Bandung: Mandar Maju, 2002), hlm 1.
} 
adalah tersusunnya Rancangan Undang-Undang (RUU) Masyarakat Adat yang memiliki semangat kebhinekaan sesuai dengan semboyan bangsa dan negara Indonesia, yaitu Bhinneka Tunggal Ika.

Semangat Bhinneka Tunggal Ika tercermin secara legal konstitusional dalam beberapa Pasal Undang-Undang Dasar Negara Republik Indonesia Tahun 1945 (UUD 1945), yaitu sebagai berikut :

"Negara mengakui dan menghormati kesatuan-kesatuan masyarakat hukum adat beserta hak-hak tradisionalnya sepanjang masih hidup dan sesuai dengan perkembangan masyarakat dan prinsip Negara Kesatuan Republik Indonesia, yang diatur dalam undang-undang". ${ }^{33}$

"Identitas budaya dan hak masyarakat tradisional dihormati selaras dengan perkembangan zaman dan peradaban". ${ }^{34}$

Rumusan dalam UUD 1945 tersebut merupakan suatu bentuk pengakuan (acknowledgment) Indonesia terhadap keberadaan Masyarakat Hukum Adat yang ada di Indonesia. Mahkamah Konstitusi pun sudah menentukan kriteria atau tolak ukur terpenuhinya ketentuan Pasal 18B ayat (2) UUD 1945 tersebut, yaitu kesatuan masyarakat hukum adat tersebut : ${ }^{35}$

1. masih hidup;

2. sesuai dengan perkembangan masyarakat;

3. sesuai dengan prinsip Negara Kesatuan Republik Indonesia; dan

4. ada pengaturan berdasarkan undangundang.
UUD 1945 merupakan hukum dasar dalam peraturan perundang-undangan ${ }^{36}$ dan menduduki posisi tertinggi dalam hierarki peraturan perundang-undangan di Indonesia. ${ }^{37}$ Pengakuan tersebut tentu memerlukan penjabaran dan pengaturan lebih lanjut dalam peraturan perundang-undangan di bawahnya, yaitu dalam bentuk undang-undang.

Secara singkat, proses pembentukan peraturan perundang-undangan mencakup tahap perencanaan, penyusunan, pembahasan, pengesahan atau penetapan, dan pengundangan. ${ }^{38}$ Salah satu output dari tahapan tersebut adalah suatu produk Rancangan Undang-Undang (RUU) yang kemudian akan dibahas bersama oleh DPR dan Presiden untuk mendapatkan persetujuan bersama. ${ }^{39}$

Proses panjang pembentukan undangundang juga terjadi saat munculnya RUU Masyarakat Adat yang sampai dengan saat ini belum juga disahkan menjadi undang-undang. Terkait hal ini, menjadi suatu hal yang menarik bahwa hukum adat dan hukum positif di Indonesia memiliki kaitan yang erat dan menjadi 2 (dua) hal yang tidak bisa dipisahkan, karena sesungguhnya hukum positif di Indonesia merupakan hukum yang bersumber dari hukum adat. Khususnya, ketentuan di bidang agraria (pertanahan). Hukum pertanahan nasional didasarkan pada hukum adat, sehingga penentuan hak-hak atas tanah dan subjek hukum yang berhak memiliki dan/atau menguasai hak atas tanah bersumber pada hukum adat. Hal ini

Indonesia (1), Undang-undang Dasar Negara Repubik Indonesia Tahun 1945, UUD 1945, Ps.18B ayat (2).

Ibid, Ps. 28I ayat (3).

Mahkamah Konstitusi RI, Putusan MKRI No. 31/PUU-V/2007, Pertimbangan Mahkamah paragraf [3.15.2].

36 Indonesia (2), Undang-undang Tentang Pembentukan Peratruan Perundang-undangan, UU No. 12 Tahun 2011, LN no. 82, TLN No.5234, Ps. 3 ayat (1).

37 Indonesia (2), op. cit., Ps. 7 ayat (1).

38 Indonesia (2), op. cit., Ps. 1 angka 1.

39 Indonesia (1), op. cit., Ps.20 ayat (2). 
menunjukkan hukum adat merupakan suatu hal yang esensial dalam hukum positif di Indonesia. Keadaan demikian memunculkan upaya tarik ulur kepentingan dalam proses legislasi undangundang (UU) yang nantinya mengakomodir Masyarakat Hukum Adat.

Ketentuan norma yang mengatur eksistensi Masyarakat Hukum Adat dalam suatu undangundang ini nantinya tidak boleh kemudian ditafsirkan lain, disimpangi, apalagi diabaikan dalam rumusan norma dalam peraturan perundang-undangan di bawah UUD 1945 yang secara jelas dan tegas mengakui adanya hak dari Masyarakat Hukum Adat di Indonesia. Keberadaan RUU Masyarakat Adat ini cukup menarik perhatian di kalangan masyarakat karena berbagai rumusan norma yang justru dianggap merugikan eksistensi dari Masyarakat Hukum Adat itu sendiri.

Pertama, RUU ini berjudul Masyarakat Adat, bukan Masyarakat Hukum Adat. Penggunaan istilah Masyarakat Hukum Adat menjadi suatu hal yang sudah familiar yang dikemukakan oleh beberapa ahli dalam berbagai literatur terkait hukum adat. Terkait penggunaan istilah tersebut, Tabel 1 di bawah ini merupakan Tabel Perbandingan Definisi Masyarakat Hukum Adat dan Masyarakat Adat.

Ter Haar dan Hazairin menggunakan istilah Masyarakat Hukum Adat yang sudah tidak asing digunakan dalam berbagai literatur hukum adat di Indonesia. Definisi yang mereka berikan pun menggambarkan eksistensi dari Masyarakat Hukum Adat yang merupakan bagian dari Masyarakat Adat. ${ }^{40}$ Berdasarkan Draft Laporan Pengkajian Hukum Tentang Mekanisme Pengakuan Masyarakat Hukum Adat yang dikeluarkan oleh Puslitbang Sistem Hukum Nasional Kementerian Hukum dan HAM RI pada tahun 2015, disebutkan bahwa masyarakat adat merupakan pengertian untuk menyebut masyarakat tertentu dengan ciriciri tertentu. Sedangkan masyarakat hukum adat merupakan pengertian teknis yuridis

\section{Tabel 1.}

Definisi Masyarakat Hukum Adat dan Masyarakat Adat

\section{Ter Haar}

Masyarakat Hukum adat sebagai (Bter Haar Bzn 1950:16) "...kelompokkelompok teratur yang sifatnya ajek dengan pemerintahan sendiri yang memiliki bendabenda materil maupun immaterial."
Hazairin

RUU Masyarakat Adat
Masyarakat Hukum Adat yang selanjutnya disebut Masyarakat Adat adalah sekelompok orang yang hidup secara turun temurun di wilayah geografis tertentu, memiliki asal usul leluhur dan/atau kesamaan tempat tinggal, identitas budaya, hukum adat, hubungan yang kuat dengan tanah dan lingkungan hidup, serta sistem nilai yang menentukan pranata ekonomi, politik, sosial, budaya, dan hukum.

Sumber : Diolah dari Soerjono Soekanto "Hukum Adat Indonesia"

40 Masyarakat Hukum Adat merupakan bagian dari Masyarakat Adat, sehingga eksistensinya adalah irisan dari Masyarakat itu sendiri yang kemudian berkembang membentuk pola hubungan hukum diantara para anggota di dalamnya. 
yang merujuk sekelompok orang yang hidup dalam suatu wilayah (ulayat) tempat tinggal dan lingkungan kehidupan tertentu, memiliki kekayaan dan pemimpin yang bertugas menjaga kepentingan kelompok (ke luar dan ke dalam), dan memiliki tata aturan (sistem) hukum dan pemerintahan ${ }^{41}$.

Dari Tabel tersebut, terdapat perubahan penggunaan istilah Masyarakat Hukum Adat menjadi Masyarakat Adat. Pembuat RUU Masyarakat Adat jelas menginginkan adanya perubahan penggunaan istilah "Masyarakat Hukum Adat yang selanjutnya disebut Masyarakat Adat.." Rumusan norma tersebut menjadi ganjil karena masih berbunyi Masyarakat Hukum Adat yang kemudian diubah menjadi Masyarakat Adat. Jika pembuat undangundang menginginkan adanya pergantian istilah, seharusnya bunyi norma langsung memberikan definisi yang jelas dan tegas "Masyarakat Adat adalah...". Perubahan penggunaan istilah ini juga terdapat dalam Ketentuan Penutup RUU Masyarakat Adat yang menyebutkan bahwa :

"Pada saat Undang-Undang ini berlaku :

a. semua istilah Masyarakat Hukum Adat yang sudah diatur dalam peraturan perundang-undangan sebelum UndangUndang ini diundangkan, harus dimaknai sebagai Masyarakat Adat sepanjang tidak bertentangan dengan UndangUndang ini.

b. semua peraturan perundang-undangan yang mengatur mengenai atau berkaitan dengan masyarakat hukum adat sebelum diundangkannya Undang-Undang ini dinyatakan tetap berlaku sepanjang tidak bertentangan dengan ketentuan dalam Undang-Undang ini".

Kemudian, pada Bagian Penjelasan Umum disebutkan bahwa "..Penyebutan masyarakat adat sebagai masyarakat hukum adat lebih dikarenakan pada penekanan kekuasaan untuk melakukan pengaturan dan pengurusan terhadap warga Masyarakat Hukum Adat...".

Ketentuan tersebut menegaskan bahwa terdapat pergantian, perubahan istilah yang sudah dikenal sebagai Masyarakat Hukum Adat (MHA) berubah menjadi Masyarakat Adat. Perubahan ini menjadi suatu hal yang menarik, karena menghilangkan kata "Hukum". Hal ini menyiratkan bahwa "hukum" menjadi suatu hal yang sudah melekat pada Masyarakat Adat itu sendiri, tanpa harus secara letterlijk disebutkan dalam suatu istilah Masyarakat Hukum Adat. Meskipun demikian, penggunaan istilah Masyarakat Adat masih bisa menjadi hal yang menarik untuk dikaji lebih dalam oleh para pakar hukum adat.

Kedua, pengakuan terhadap Masyarakat Adat harus memenuhi berbagai persyaratan dan tahapan yang ditentukan dalam rumusan RUU Masyarakat Adat. Pemerintah akan melakukan pendataan terhadap Masyarakat Adat yang memenuhi berbagai persyaratan yang telah ditentukan dalam RUU Masyarakat Adat yang kemudian dijadikan dasar untuk pengakuan terhadap Masyarakat Adat. Setelah dilakukan pendataan, masih terdapat 4 (empat) tahapan yang harus dilalui oleh Masyarakat Adat untuk memperoleh pengakuan, yaitu identifikasi, verifikasi, validasi, dan penetapan.

Pada bagian Penjelasan Umum paragraf ke-4 RUU Masyarakat Adat, disebutkan bahwa sebelum mendapatkan perlindungan dan pemberdayaan serta hak-haknya terlebih dahulu dilakukan proses pengakuan yang merupakan

41 Puslitbang Sistem Hukum Nasional, Kemenkumham RI, Draft Laporan Pengkajian Hukum Tentang Mekanisme Pengakuan Masyarakat Hukum Adat (Jakarta,2015), hlm. 1. 
bentuk legalitas formal. Menurut hemat penulis, hal ini merupakan suatu fallacy ${ }^{42}$ dalam peraturan perundang-undangan. Konstitusi Indonesia, UUD 1945 secara jelas telah memberikan pengakuan kepada Masyarakat Adat di Indonesia. Pengakuan dari UUD 1945 merupakan bentuk legalitas konstitusional yang merupakan bentuk dari legalitas formal itu sendiri. Sehingga, di sini terdapat fallacy dari logika hukum dalam RUU Masyarakat Adat.

Masyarakat Adat adalah subjek hukum alamiah. Beberapa Masyarakat Adat bahkan hadir sebelum negara ini merdeka. Masyarakat Adat bukan dibentuk oleh pemerintah atau negara, melainkan terbentuk secara alamiah karena eksistensinya hadir bukan sebagai suatu lembaga. Posisi Negara melalui pemerintah hanya cukup mengakui dan menghormati keberadaan hak Masyarakat Adat sebagai manifestasi kehadiran negara di tengah setiap elemen masyarakat sesuai dengan amanat konstitusi. Sehingga, terlebih dahulu perlu adanya pengakuan terhadap subjeknya (Masyarakat Adat), kemudian objeknya (wilayah adat, tanah adat). Jika gagasan ini dibalik menjadi pengakuan terhadap objek terlebih dahulu, maka pemerintah sedang melahirkan RUU yang berpotensi mandul untuk diimplementasikan. Hal ini karena persoalannya adalah mengidentifikasi subjek yang mengelola objek hak yang telah diakui. ${ }^{43}$

Di samping itu, berbagai prosedur tersebut jelas memberikan kerugian bagi Masyarakat Adat yang telah ada, hidup, dan berkembang sejak lama di berbagai daerah di Indonesia. Sifat dan karakteristik Masyarakat Adat di Indonesia yang tradisional dan cenderung konservatif. $\mathrm{Hal}$ ini jelas akan membawa dampak negatif bagi Masyarakat Adat nantinya, karena rumitnya prosedur yang harus mereka tempuh demi mendapatkan pengakuan dari Pemerintah.

Ketentuan demikian jelas bertentangan dengan UUD 1945, yang jelas memberikan dasar hukum bagi pengakuan terhadap eksistensi Masyarakat Adat yang telah ada, hidup, dan berkembang jauh sebelum Indonesia merdeka secara de facto pada 17 Agustus 1945. Perumusan norma dalam RUU Masyarakat Adat tersebut akan memberikan ketidakpastian hukum bagi Masyarakat Adat yang membutuhkan perlindungan dan pemberdayaan dari Pemerintah sebagai pelaksana jalannya pemerintahan.

Ketiga, terdapat ketentuan yang menimbulkan kekosongan hukum bagi subjek hukum tertentu yang melanggar ketentuan dalam RUU Masyarakat Adat. "Setiap Orang dilarang menghalang-halangi Masyarakat Adat dalam mengelola dan memanfaatkan sumber daya alam di Wilayah Adat sebagaimana dimaksud dalam Pasal 23. Pelanggaran terhadapnya dipidana dengan pidana penjara paling lama 5 (lima) tahun dan/atau denda paling banyak Rp. 5.000.000.000,- (lima milyar rupiah)."

Sekilas tidak terlihat ada yang kurang dalam bunyi rumusan dalam RUU Masyarakat Adat tersebut. Namun, apabila dicermati lebih lanjut, bunyi rumusan tersebut hanya memberikan sanksi pidana bagipelanggarPasal23, yangsubjek

\footnotetext{
42 Fallacy can refer either (a) a kind of error in an argument, (b) a kind of error in reasoning, (c) a false belief, or (d) the cause of any of the previous errors including what are normally referred to as "rhetorical techniques". Lihat "Fallacies", https://www.iep.utm.edu/fallacy/ (diakses pada 26 Januari 2019).

43 "Penantian Panjang RUU Masyarakat Adat", https://news.detik.com/kolom/d-3975715/penantian-panjangruu-masyarakat-adat (diakses pada 22 Januari 2019).
} 
hukumnya adalah "Setiap Orang". Sebagaimana kita ketahui, dalam perkembangannya, subjek hukum pidana bisa berupa Badan Hukum. ${ }^{44}$ Ketentuan dalam rumusan tersebut menjadi kurang karena belum mengakomodir subjek hukum pidana lainnya, yaitu Badan Hukum. Hal ini mengingat eksistensi Masyarakat Adat yang memiliki tanah bersama, yaitu tanah ulayat $^{45}$ yang rentan diambil alih penguasaan dan/atau kepemilikannya oleh berbagai pihak.

Terkait sumber daya alam di wilayah adat, menjadi suatu hal yang menarik adanya Putusan Mahkamah Konstitusi Nomor 35/PUU-X/2012 yang telah diucapkan pada tanggal 16 Mei 2013 dalam sidang terbuka untuk umum terkait hutan adat ${ }^{46}$. Mahkamah berpendapat bahwa ketentuan konstitusional dalam Pasal 18B ayat (2) UUD 1945 mengandung hal penting dan fundamental, yaitu Masyarakat Hukum Adat secara konstitusional diakui dan dihormati sebagai "penyandang hak" yang demikian tentunya dapat pula dibebani kewajiban, yang telah ditentukan dasar-dasar konstitusionalnya dalam Pasal 33 ayat (2), ayat (3), dan ayat (4) UUD 1945.

"[3.12.4] ... Masyarakat hukum adat berada dalam posisi yang lemah karena tidak diakuinya hak-hak mereka secara jelas dan tegas ketika berhadapan dengan negara dengan hak menguasai yang sangat kuat. Berdasarkan
Pasal 22 Rio Declaration on Environment and Development menyatakan bahwa masyarakat hukum adat mempunyai peranan penting dalam pengelolaan dan pembangunan lingkungan hidup karena pengetahuan dan praktik tradisional. Oleh karenanya negara harus mengenal dan mendukung entitas, kebudayaan, dan kepentingan mereka serta memberikan kesempatan untuk berpartisipasi aktif dalam pencapaian pembangunan yang berkelanjutan (sustainable development)."

Dari berbagai uraian tersebut, aspek terpenting dari pengaturan terhadap Masyarakat Hukum Adat adalah terkait pengakuan dari eksistensi mereka. Dalam pertimbangan Mahkamah dalam Putusan Nomor 35/ PUU-X/2012, Mahkamah berpendapat bahwa syarat pengakuan dan penghormatan masyarakat hukum adat dalam frasa "sepanjang kenyataannya masih ada dan diakui keberadaannya", harus dimaknai sepanjang masih hidup dan sesuai dengan perkembangan masyarakat, karena hukum adat pada umumnya merupakan hukum yang tidak tertulis dan merupakan living law, artinya merupakan hukum yang diterima (accepted) dan dijalankan (observed) serta ditaati oleh masyarakat yang bersangkutan karena memenuhi rasa keadilan bagi mereka dan sesuai serta diakui oleh konstitusi. ${ }^{47}$

44 Pertanggungjawaban korporasi sebagai subjek hukum pidana pertama kali diperkenalkan dalam UU No. 23 Tahun 1997 Tentang Pengelolaan Lingkungan Hidup sebagaimana telah diubah dengan UU No. 32 Tahun 2009 Tentang Perlindungan dan Pengelolaan Lingkungan Hidup.

45 Tanah ulayat diartikan sebagai tanah bersama para warga masyarakat hukum adat yang bersangkutan. Sedangkan hak penguasaan atas tanah masyarakat hukum adat itu dikenal dengan hak ulayat. Lihat "Perbedaan Tanah Ulayat dengan Tanah Desa", https://www.hukumonline.com/klinik/detail/lt59409b28e703e/perbedaantanah-ulayat-dengan-tanah-desa/ (diakses pada 28 Januari 2019)

46 Putusan MK ini memberikan pengaturan hubungan antara hak menguasai negara dengan hutan negara dan hak menguasai negara dengan hutan adat. Terhadap hutan negara, negara memiliki kewenangan penuh mengatur peruntukan, pemanfaatan, dan hubungan hukum yang terjadi di wilayah hutan negara. Sedangkan terhadap hutan adat, wewenang negara dibatasi.

47 Mahkamah Konstitusi RI, op. cit., Paragraf [3.13.2]. 
Masyarakat Hukum Adat harus diakui, dihargai, dan diakomodir oleh Pemerintah dalam bentuk pengaturan konkret dalam suatu penormaan undang-undang, juga peraturan pelaksana yang bersifat teknis dan tidak mempersulit serta memberikan kerugian bagi Masyarakat Hukum Adat itu sendiri. Keberadaan RUU Masyarakat Adat bagaikan 2 (dua) sisi koin yang saling berlawanan. Sisi positif yang dapat diambil adalah terlihatnya upaya positif pemerintah untuk mengakomodir dan mengatur eksistensi Masyarakat Adat yang telah ada, hidup, dan berkembang dalam masyarakat. Perumusan norma di dalamnya pun tak lepas dari keluarnya Putusan MK No. 35/PUU-X/2012 terkait hutan adat. Namun, berbagai rumusan norma dalam RUU tersebut justru akan menimbulkan berbagai permasalahan dan mengancam eksistensi dari Masyarakat Hukum Adat itu sendiri.

Jika kemudian RUU Masyarakat Adat ini disahkan tanpa adanya koreksi, maka ada kemungkinan besar akan diajukan pengujian undang-undang di Mahkamah Konstitusi. Mengingat bahwa berbagai rumusan norma di dalamnya bertentangan dan tidak sesuai dengan semangat Bhinneka Tunggal Ika dalam UUD 1945.

Eksistensi Masyarakat Hukum Adat harus mampu diakomodir dalam undang-undang yang mengatur hal terkait. Ketentuan yang ada harus berdasarkan pada ketentuan dalam UUD 1945 yang secara legal konstitusional sudah mengakui adanya Masyarakat Hukum Adat itu sendiri. Peraturan perundang-undangan yang ada sudah seharusnya membawa semangat kebhinekaan demi tercapainya integrasi bangsa dalam kehidupan bermasyarakat, berbangsa, dan bernegara dalam upaya mewujudkan pembangunan hukum nasional yang berkesinambungan.

\section{Penutup}

Undang-Undang Dasar 1945 mengakui keberlakuan hukum adat sebagai hukum yang tertulis dan tidak tertulis. Hukum adat tumbuh, berkembang dan terus dipertahankan dalam masyarakat adat berdasarkan wilayah adat masing-masing. Penegakan hukum adat di Indonesia mengacu kepada hukum yang hidup dan masyarakat setiap daerah memilik cara penyelesaian sendiri mengacu kepada hukum adat. Hingga sekarang keberlakuan Hukum adat masih terus dipertahankan walaupun pengaturan hukum adat belum jelas dalam sistem hukum nasional. Oleh sebab itu, hukum tidak tertulis sudah seharusnya diwujudkan ke dalam hukum positif yang walaupun tidak dapat merangkum semua hukum tidak tertulis antar daerah setidaknya dapat menjadi alat untuk mengakomodir sistem hukum tidak tertulis dalam hukum nasional.

Politik legislasi hukum tidak tertulis, dalam hal ini terkait Masyarakat Hukum Adat dalam pembangunan hukum nasional dapat ditinjau dari keluarnya Rancangan Undang-Undang Masyarakat Adat. Berbagai rumusan dalam RUU tersebut justru menunjukkan adanya kepentingan politik dalam proses legislasi, salah satunya adalah adanya prosedur pengakuan Masyarakat Adat melalui berbagai tahapan yang rumit dan akan mengancam eksistensi dari Masyarakat Hukum Adat itu sendiri. Hal ini menunjukkan bahwa RUU Masyarakat Adat tidak memiliki semangat kebhinekaan sebagaimana terdapat dalam UUD 1945 demi terwujudnya hukum pembangunan nasional yang berkesinambungan. 
Hukum adat seharusnya tetap dipertahankan dalam sistem hukum Indonesia. Sebagai hukum yang hidup dan bagian dari kebudayaan yang mencerminkan sikap dan perilaku dalam kehidupan masyarakat hukum adat. Keberlakuan penegakan hukum adat berdasarkan wilayah masing-masing hukum adat yang berbeda-beda setiap daerah masyarakat hukum adat.

Politik legislasi dalam RUU Masyarakat Adat harus mampu mencerminkan semangat kebhinekaan sebagaimana terdapat dalam konstitusi Indonesia, Undang-Undang Dasar 1945. Koreksi terhadap Rancangan UndangUndang Masyarakat Adat yang ada saat ini menjadi suatu hal yang wajib dilakukan oleh DPR demi terciptanya pembangunan hukum nasional yang berkesinambungan.

\section{Daftar Pustaka}

\section{Buku}

Arliman, Laurensius, Hukum dan Kesadaran Masyarakat (Yogyakarta: Penerbit Deepublish, 2015).

Faisal, Menerobos Positivisme Hukum (Yogyakarta: Rangkang Education, 2010).

Fajar, Mukti dan Yulianto Achmad, Dualisme Penelitian Hukum Normatif dan Empiris (Yogyakarta: Pustaka Pelajar, 2010).

Fatahillah, Syukur, Mediasi Yudisial di Indonesia (Bandung: Mandar Maju, 2002).

Koesno, Mohammad, Hukum Adat Sebagai Suatu Model Hukum, Bagian I (Historis) (Bandung: Mandar Maju, 1992).

Kusumaatmaatmadja, Mochtar, Konsep-konsep hukum dalam Pembangunan (Pusat studi Wawasan Nusantara: Alumni Bandung, 2002).

Mahyuddin, H. Suardi, Hukum Adat Minangkabau dalam Sejarah Perkembangan Nagari Rao-Rao (Citatama Mandiri, 2002).

Marzuki, Peter Mahmud, Penelitian Hukum (Jakarta: Kencana, 2011).

Munir, Lukman, (ed.), Bunga Rampai Menuju Revitalisasi Hukum dan Adat Aceh (Banda Aceh: Yayasan Rumpun Bambu dan CSSP Jakarta, 2003).
Setiadi, Tolib, Intisari Hukum Adat Indonesia dalam Kajian Kepustakaan (Bandung: Alfabeta, 2008).

Sulaiman, M. Isa dan H.T. Syamsuddin, (ed.), Pedoman Umum Adat Aceh: Peradilan dan Hukum Adat (Banda Aceh: MAA Provinsi NAD, 2007-2008).

Tilaar, H.A.R, Pendidikan Multikultural Dan Revitalisasi Hukum Adat Dalam Perspektif Sejarah (Departemen Kebudayaan dan Pariwisata, 2005).

Widnyana, I Made, Kapita Selekta Hukum Pidana Adat (Bandung: Eresco, 1993).

\section{Makalah/Artikel/Prosiding/Hasil Penelitian}

Abubakar, Ali, "Urgensi Penyelesaian Kasus Pidana Dengan Hukum Adat", http: //www.academia. edu /19807132/ URGENSI_ PENYELESAIAN_ KASUS PIDANA_DENGAN_HUKUM_ADAT (diakses pada 26 Januari 2019).

Draft Laporan Pengkajian Hukum Tentang Mekanisme Pengakuan Masyarakat Hukum Adat (Jakarta: Puslitbang Sistem Hukum Nasional Kemenkumham RI, 2015).

Hasil Seminar Hukum Adat dan Pembangunan Hukum Nasional, dalam buku Rosdalina, Hukum Adat (Yogyakarta: Penerbit Deepublish, 2017).

Kalengkongan, Stevania Bella, "Kajian Hukum Pidana Adat Dalam Sistem Hukum Pidana Indonesia", Jurnal Lex Crimen Vol. VI/No.2/Mar-Apr/2017.

"Pendekatan Hukum Adat Dalam Menyelesaikan Konflik Masyarakat Pada Daerah Otonom", Jurnal Kriminologi Indonesia Vol. 2 Nomor I Januari 2002.

Pratama, Hendri, "Penyelesaian Perkara Pidana Anak Secara Adat Lampung Megow Pak Tulang Bawang Dalam Rangka Restorative Justice", Fiat Justisia Journal of Law, Volume 10 Issue,1, January-March 2016.

Toruan, Chandra Lumban, "Kearifan Lokal Sebagai Asas Penegakan Hukum Untuk Keadilan Yang Substansi", http://www.academia.edu /23515607/KEARIFAN_LOKAL_SEBAGAI_ASPEK PENEGAKAN _HUKUM _UNTUK_KEADILAN YANG_SUBSTANSI (diakses pada 22 Januari 2019).

\section{Peraturan Perundang-Undangan}

Undang-Undang Dasar Negara Republik Indonesia 1945. 
Undang-Undang Nomor 5 Tahun 1960 Tentang Peraturan Dasar Pokok-Pokok Agraria.

Undang-Undang Darurat Nomor 1 Tahun 1951 tentang Tindakan-Tindakan Sementara

Untuk Menyelenggarakan Kesatuan Susunan Kekuasaan dan Acara Pengadilan-Pengadilan Sipil (LN 1951 Nomor 9).

Undang-Undang Nomor 48 Tahun 2009 tentang Kekuasaan Kehakiman.

Undang-Undang Nomor 16 Tahun 2004 tentang Kejaksaan Republik Indonesia.

\section{Putusan Pengadilan}

Putusan Mahkamah Konstitusi Nomor 35/ PUU-X/2012.

\section{Internet}

"Fallacies", https://www.iep.utm.edu/fallacy/ (diakses pada 26 Januari 2019).

"Penantian Panjang RUU Masyarakat Adat", https:// news.detik.com/kolom/d-3975715/penantianpanjang-ruu-masyarakat-adat diakses pada 22 Januari 2019).

Perbedaan Tanah Ulayat dengan Tanah Desa", https://www.hukumonline.com/klinik/ detail/lt59409b28e703e/perbedaan-tanahulayat-dengan-tanah-desa/ (diakses pada 28 Januari 2019). 
"Halaman ini dikosongkan" 